\title{
消化器病センターにおける食道の診療
}

遠藤光夫, 中山恒明, 木下祐宏, 鈴木 茂, 井手博子, 吉田 操, 林 恒男, 小藤田礼章

\section{The Present Condition of the Diagnostic and the Therapeutic Procedures of the Esophageal Cancer in Our Hospital}

\author{
M. Endo et al, \\ Department of Surgery, Institute of Gastroenterlogy, Tokyo Women's Medical College
}

\begin{abstract}
The present condition of the diagnostic and the therapeutic procedures of the esophageal cancer in our hospital was reported. Among the visited patients of esophageal diseases, the ones suffered from the espphageal cancer were occupied in the majority. To improve the diagnostic results, the endoscopic procedures by the fiberoptic esuphagoscope were stressed. To improve the operative results, several modifications were reported about the therapeutic and operative procedures. Especially, the early diagnosis and the adequate adjuvant therapeutics of the $\epsilon$ sophageal cancer were most important things. Until now, the early esophageal cancer has been found in fourteen patients.
\end{abstract}

\section{I はじめに}

第25回総会で，橋本会長は「気管食道科診療 の将来」というテーマを計画され，司会の永井 教授より,「消化器病センターにおける食道の 診療と治療」という副題で, 発表の機会をあた えられた。当センターは, 消化器といら臓器を 中心に内科, 外科が一しょになつて働いている 従来の講座制と異つた形をとつているが，気管 食道科領域には, 消化器のなかの「食道」とい うことで接触している施設である。而も, 普通 の気管食道科の食道の部とも一寸ニュアンスが ちがつている。気管食道科の将来といらことに ついて，一資料になればと考え，当センターの

東京女子医大消化器病センター外科
現状についてのべてみるつもりである。

\section{II 疾患別統計}

一年間の外来患者より, 臓器別疾患統計をみ てみると，胃疾患 $57 \%$ ，食道疾患 $13 \%$ ，胆道疾 患 $10 \%$, 大腸疾患 $9 \%$, 肝疾患 $8 \%$, 膵疾患 3 $\%$ と，やはり胃潰瘍，十二指腸潰瘍を中心とす る胃疾患が圧倒的に多くなつている。

食道疾患について，過去 7 年間の外来疾患別 統計をみると, 食道癌, 食道噴門癌が最も多 く，全体の66\%を占めている（表 1 ）。係室, 食道裂孔へルニアもかなりの数があるが，X線 検査の際, 食道を 1 ～枚必ずとつておくよう にしていること, 撮影体位も, 臥位を含めてか なり多くの体位で噴門部付近をチュックしてい るということなどで，その多くが無症状のまま 
表 1 外来に拈ける食道疾患統計

(1965 1971)

\begin{tabular}{|c|c|c|c|}
\hline 疾 & 患 & 例 & 数 \\
\hline 食 道 & 癌 & 863 & \\
\hline 食 道 & 噴 門 癌 & 283 & \\
\hline 肉 & 腫 & 4 & \\
\hline 良性腫 & 瘍 & 16 & \\
\hline 潰 & 瘍 & 36 & \\
\hline 馝 & 室 & 223 & \\
\hline アカラジ & & 96 & \\
\hline 食道裂孔 & しヘルニア & 145 & \\
\hline 静 脈 & 瘤 & 71 & \\
\hline & 計 & 1737 & \\
\hline
\end{tabular}

で発見されている。食道潰瘍，食道炎では，そ の大部分に食道裂孔へルニアを伴うが，食道裂 孔ヘルニアで, 内視鏡所見から食道炎を伴うの は，半数にもすぎない。

\section{III 食道鏡検査の現況}

食道関係の愁訴のある患者には，ほとんど全 員に食道及び胃のX線造影検查をおこなつてい る。X線検查後，食道鏡検查にまわす場合を考 えると，(1)X線所見で所見がはつきりしている が，生検診断などを含め，内視鏡検查を併用し たい場合，(2)X線所見上疑問のある場合，(3) X 線所見上は全く異常を認めないが，食道に関す る不定愁訴が永くつうく場合，にまとめること ができる。このうち，(2)についてはX線フィル ムの上で，何らかの所見があり，確診に，ま た，鑑別診断上からも必要であるが，(3)もかな り重要である。食道が縦隔と体の奥にあたるた め, 一本の筒状といら簡単な構造であるにかか わらず，X線検査のとき圧迫したり，触診をし たりできない関係で，おのうかか検查に限界が あつて, 食道鏡検查の役割が大きくなつてく る。例えば, $1.8 \mathrm{cmX} 1.5 \mathrm{~cm}$ の粘膜層に限局す るびらん様表在癌が，あとからふり返つてみて む所見をよめなかつたこともあり，自験例の早 期癌の第 1 例が X線検查では異常なしといわれ ながら，食道に何かつかえる感じがつうくくとい らことで，内視鏡検査を依頼され発見されたと か，又，びらん性食道炎，軽度の静脇瘤など
も，内視鏡検查で，はじめて診断されるなど， 凹凸の僅かな所見に対する内視鏡検査の価值は かなり高いものである。

外来を訪れる食道に関する不定愁訴をもつ患 者の殆んどが，実際食道に病変をみないのであ るが, 早期癌の愁訴は, 食道の不定愁訴が一番 多いことからも，一応はチュックして検査をお こなうようにしている。

食道鏡検査総数は，7692回である。同一症例 に, 経過追求のための重複検查を含むが，疾患 別では食道癌及び下部食道噴門癌が最も多く, 全体のほぼ $1 / 3$ をしめている。また, 食道外科が 主となるため, 食道再建術々後の検査例が多い のも, 他の気管食道科での診療内容と異なると ころであろう。

食道鏡の種類については, はじめは硬性直達 鏡 (Jackson type), さらに, telěscope を用い た撮影用食道鏡（町田C型）を用いた。Hirschowitz のファイバースコープを開発後, LoPresti（1964）が柔軟な食道ファイバースコープ

表 2 食道鏡検查総数

（東京女子医大消化器病センター・1965 1972）

\begin{tabular}{|c|c|c|}
\hline 疾 & 患 & 症 例 数 \\
\hline \multirow{2}{*}{\multicolumn{2}{|c|}{$\begin{array}{l}\text { 頸部食道癌 } \\
\text { 胸部食道癌食道噴門癌 }\end{array}$}} & 124 \\
\hline & & 2254 \\
\hline \multicolumn{2}{|c|}{ 胃癌 } & 201 \\
\hline \multirow{2}{*}{\multicolumn{2}{|c|}{ 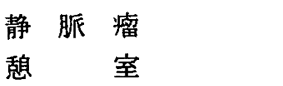 }} & 323 \\
\hline & & 189 \\
\hline \multicolumn{2}{|c|}{ アカラジア } & 118 \\
\hline 肉 & 腫 & 14 \\
\hline & 腫 & 11 \\
\hline \multicolumn{2}{|c|}{ 粘膜下腫瘍 } & 52 \\
\hline \multicolumn{2}{|c|}{ 食道炎 } & 297 \\
\hline 潰 & 瘍 & 164 \\
\hline \multicolumn{2}{|c|}{ 狭窄 } & 55 \\
\hline \multicolumn{2}{|c|}{ 腐蝕性狭窄 } & 13 \\
\hline \multicolumn{2}{|c|}{ 裂孔ヘルニア } & 195 \\
\hline 異 & 物 & 43 \\
\hline \multicolumn{2}{|c|}{ 食道再建術々後 } & 1373 \\
\hline \multicolumn{2}{|c|}{ 正 常 } & $222 \bar{T}$ \\
\hline \multirow[t]{2}{*}{ その } & 他 & 39 \\
\hline & 計 & 7692 \\
\hline
\end{tabular}


表 3

\section{兴種にる食道鏡㭘査総数}

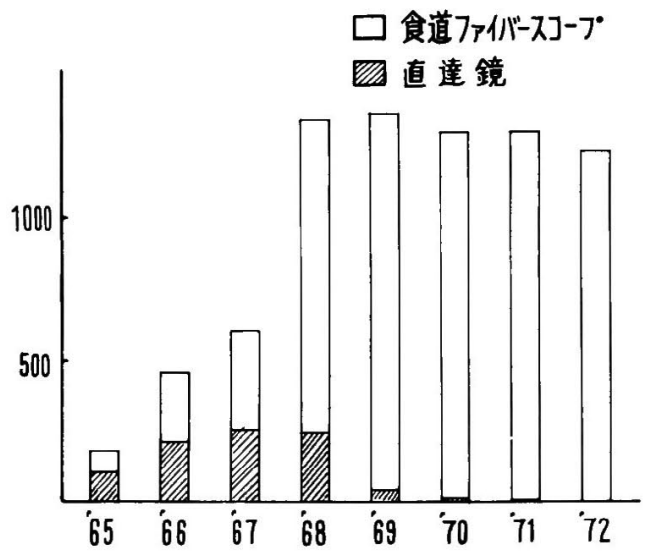

をその使用経験とともにはじめて報告した。一 方わが国でも，オリンパス光学，町田製作所で 独自に開発がすすめられ，1965年の臨床報告以 来，次第に改良もす寸んで，現在では，国産の 食道ファイバースコープが，はるかに優れたも のとして広く普及, 日常の臨床に応用されるよ うになつた。食道ファイバースコープの利用度 がますにつれ，段々と硬性直達鏡の使用が減つ てきたが，特に1968年以降は，年間食道鏡検査 数が大体1200 1300回と一定している ところ で, 硬性直達鏡の使用回数は70年では10回, 71 年 1 回，72年は 0 である（表 3 )。これは当セ ンターが消化器疾患の診療で, 耳鼻科関係の患 者と性質がちがつているというものの，ファイ バースコープ検査が，段々に，硬性鏡に委悋て いた領域にまで応用範囲が広がつたこともあ る。

これまで食道鏡検查で直達鏡を併用したもの を考えてみると，診断面では，その優れた記録 性のためであり, 治療面では, 異物の除去, 食 道狭窄部の拡張などであつた。撮影用食道鏡 は，直達鏡に併用する内套管として telescope を用いるので、レンズ系で撮影された写真は寸 ばらしく，これは，ファイバースコープでは， この写真に近ゔけられても決して同じものはで きないと思うのである。

しかし，ファイバースコープも，段々とファ
イバーの質も向上し，製作技術も改善され，イ メージがよくなつていて, 光源として, 高輝度 光源（フラッシュ光源）も開発され，1/100 前後 の速いシャッタースピードで撮影できるためブ レもなくなり，さらに近距離部分での焦点調節 能からシャープな近接像がえられ，現在は記録 性も向上し, 臨床面の実際ではレンズ系 telescope でとり直す必要はなくなつている。

次に, ファイバースコープの治療面への利用 についてふれてみると, その一つは異物の摘出 である。ファイバースコープによる異物の摘出 にも摘出用鉗子が最も大切で, ファイバースコ 一プの生検用鉗子孔から捰入できる異物鎂子を 考案した。この銝子は生検鉗子と同じ操作で先 端部の開閉ができ, 先端部は開大時には $1.5 \mathrm{~cm}$ も開き（図 1)，把持力としては，1kg の分銅 を吊下げられる位である。異物摘出の操作につ いては, 硬性直達鏡での操作法と同じにしてい るがフファイバースコープでは送気により食道 内腔を拡張してみることのできること，接眼部 で対象物を拡大観察できること。吸引操作の自 働化で, 食道内腔の洗滌が容易である, などに より，異物の状態を細かく観察することができ る。また，食道内腔を遊走するような小異物の 把持が容易であることも特徴である。現在まで の摘出例は57例である。その多くは食物塊であ るが, 義歯, 貨幣, 梅干のたね，玩具なども少 数例づつではあるが経験している。さらに，フ アイバースコープの場合, 直達鏡とちがって胃 内の異物も同様の操作で容易に摘出することが できることも利点である，まだ偶発症の経験は

図 1

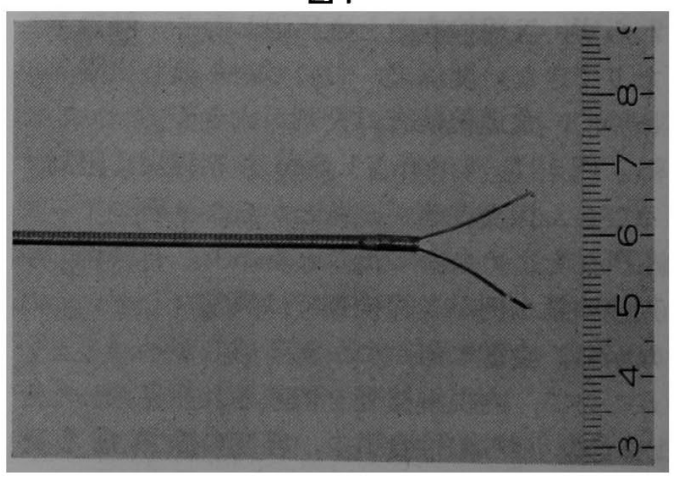


表 4 食道ファイバースコープによる摘出異物例 $(1970-1973,6)$

\begin{tabular}{|c|c|}
\hline \\
\hline 食 & 41 \\
\hline 貨幣 & $5(2)$ \\
\hline 梅干のたね & 2 \\
\hline コイン状プラスチック & 1 \\
\hline 薬荗PTP包装 & 1 \\
\hline 玩具 (ゼンマイ巻き) & 1 \\
\hline スプーン & 1 \\
\hline 食道挿管用チューブ & 1 \\
\hline 錠 & 1 \\
\hline 診断用腸紐 & $1(1)$ \\
\hline 義歯 & 2 \\
\hline 計 & $57(3)$ \\
\hline
\end{tabular}

（）内は胃内異物

図 2

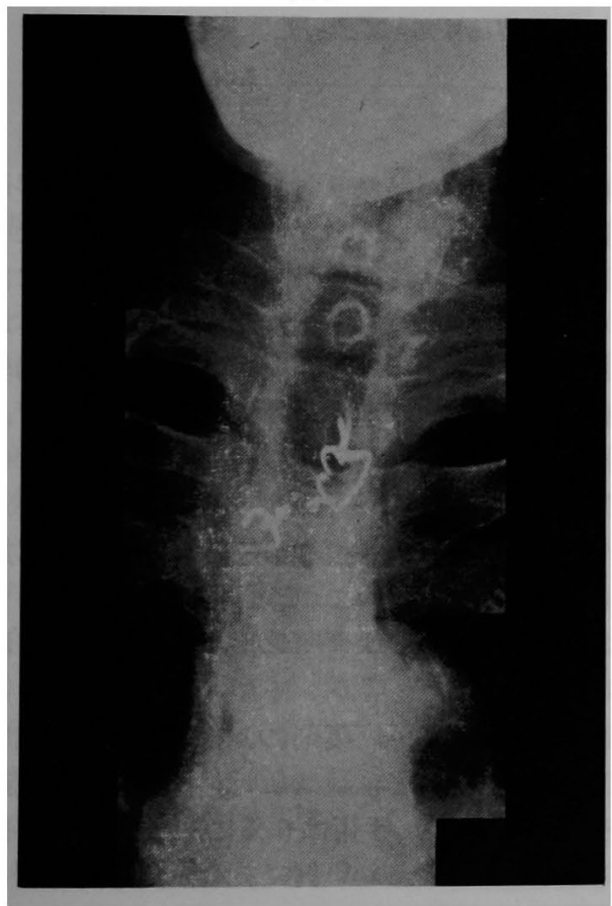

ないが，今後いろいろと検討を加えていく分野 と考えている（表 4)。

1 例を供覧すると, 図 2 のX線写真で上部食 道に義歯の金属性フックが嵌在してみられた。 全麻下，食道ファイバースコープを挿入する と, 上部食道に義歯の歯の部分が白くみえ，だ
図 3

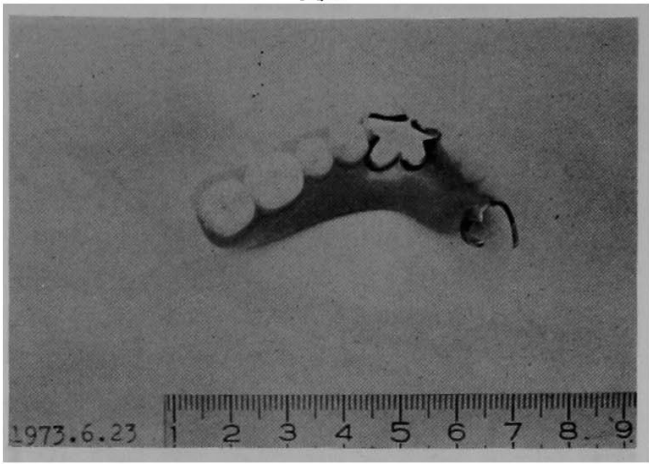

が，金属のフックはみえなかつた。異物鉗子で 把持し，そのまま引張つたところ抵抗が強く, $90^{\circ}$ 左へ回転したところ，抵抗が少なくなり抜 去できた。図 3 は摘出した義歯でかなり大き く, 除去の際には, 左端の歯の部分を挾んでと り出したわけである。

食道の瘕痕性狭窄の拡張に, 従来は直達鏡 下，鯨骨ブジーを用いてきた。われわれのとこ ろでは腐触性のものより食道再建術々後の吻合 部の症痕性狭窄が多く, そのなかでも腹腔内食 道再建術術後では, 吻合部がかなり腹側へ偏位 することが多く, 直達鏡の操作では頭部をぐん と下ろした極端な low position にしないとみ えないこともあつて, 患者への侵襲はかなりの ものがある。最近は食道ファイバースコープ 下, 高周波電気凝固器を用いて吻合部を焼灼切 開し，次いで，特殊なブジーで，ひきつづき拡 大するようにしている。このブジーは，芯に金 属のらせんを用い腰を強くしたもので，而も先 端部を手許の操作で $60^{\circ}$ まで, 自由に曲げられ るようにしたもので（図 4), X線透視下，直 達鏡を使用せず狭窄部の拡張をはかる。バリウ ムを一口のませて狭窄部の状態をみつつ経口的 にブジーを入れ，X線上，先端部を適当にまげ ながら狭窄部に合わせ，ブジールングをおこな うものである。直達鏡操作という専門的な技術 を要せず毎日でもくり返せる点, 一般的であ る。

このように診断面だけでなく従来硬性直達鏡 に全面的に委ねられてきた部門へもファイバー スコープが分担できるようになつたことが，食 
図 4

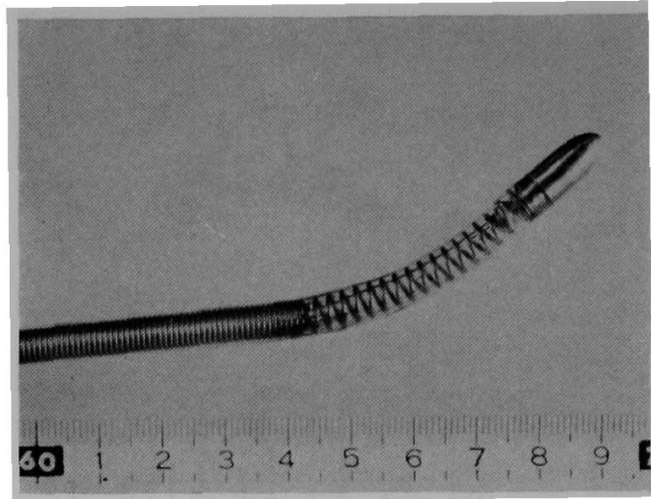

道鏡検查で直達鏡の使用回数の減つてきたこと と考えている。ファイバースコープは確かに革 命的なものではあろうが，食道鏡の分野では硬 性直達鏡にす心゙てとつてかわるということはあ りえないと思われる。しかし，やはり患者の負 担は少なく，而も技術的困難性をなくす内視鏡 検査の晋及も, 食道科の診療の将来という面で 考えていかねばならないことと思つている。

\section{IV 食道癌の診療}

食道疾患のらちでは，食道癌が最も多く，当 センターでの胸部食道癌の実態を入院患者統計 でみてみると，過去 8 年間の総数 808 例中，切 除例は456例 (56\%), 非切除例は352例 (44\%) であるが，切除率の56\%という值は胃癌に比心 てかなり低い。非切除とした理由についてみて みると，局所々見からというのが最も多く $47 \%$ をしめ, 遠隔リンパ節転移また他臟器転移のは つきりしていたもの $20 \%$ ，心，肺，肝，腎など の障害があり，一般状態の不良のもの $14 \% ，$ 高 令，手術を拒否したもの15\%となつている。そ の各々の平均生存期間は，大体 6 ケ月 と悪い が，そのなかでは，高令のためとか，手術を拒 否したためとかで，非切除になつたものは平均 12ケ月とやや長くなつている（表 5 ）。

このうち局所々見からとしたものをX線所見 で更に分析してみると，癌部の陰影欠損が大き く $9 \mathrm{~cm}$ 以上もあるもの, と癌腫が周囲臓器へ強 く浸潤していると思われたものが62\%になり， 穿孔, 出血などの合併症がなくても，進行しす
表 5 非切除の理由と生存期間

(1965 1972)

\begin{tabular}{|c|c|c|}
\hline 非切除理 由 & 症例数 & $\begin{array}{l}\text { 平均生存数 } \\
\text { 月 }\end{array}$ \\
\hline 局 所 所 見 & 165 & 7.0 ヶ月 \\
\hline $\begin{array}{l}\text { 遠隔リンパ節転移及び他臟 } \\
\text { 器転移 }\end{array}$ & 70 & 4.9 .万 月 \\
\hline 心・肺 - 肝 - 腎障害 & 49 & 7.7 ヶ月 \\
\hline 高令及び手術拒否 & 54 & 12.0 ヶ月 \\
\hline そ の 他 & 14 & \\
\hline 計 & 352 & \\
\hline
\end{tabular}

表 6 局所所見の分析

癌部の陰影欠損が $9 \mathrm{~cm}$ 以上もあるもの 癌の浸潤が周囲臟器に強くおよんでい ると疑われたもの

癌部に穿孔，穿通像をみるもの

食道壁内転移のはっきりしているもの

頸胸境界部にあって放射線治療を優先 したもの

$39 \%$

23

14

8

16

ぎているものがかなりある。X線上穿孔，穿通 像をみたものは $14 \%$ ，食道壁内転移を認めたも の $8 \%$ あるる。このほか, 癌が頸胸境界部にあ つて，放射線治療を優先したものが16\%みられ た。現在ではいるいろ問題はのこるが，頸胸境 界部にあるという理由だけでは非切除とせず， 遠隔時の愁訴も考え，皘極的に切除を考えてい る(表 6 )。

非切除食道癌に対する治療として，88\%に放 射線治療をおこなつている。抗癌剤治療は $3 \%$ にすぎない。ブレオマイシン，多剤併用療法 （5FU十マイトマイシントキロサイドなど）を おこなつているが，薬剤による著効例は現在ま でのところ殆んど経験はない。胃瘦造設，食道 内挿管，By-pass 手術は $6 \%$ に，また $3 \%$ は何 の処置もおこなえない例である。食道内挿管と か By-pass 手術任経口摄取を可能にはするが， 食道気管(支)瘦などの患者に対してその生存期 間をのばすことはできなかつた。By-pass 手術 には，おもに胃管を用い，胸壁前皮下の経路で 挙上, 頸部食道と吻合している。食道内捰管法 は全麻下，胃切開を括こない，経口的に插管し ている。 
気食会報一 25 巻

図 5

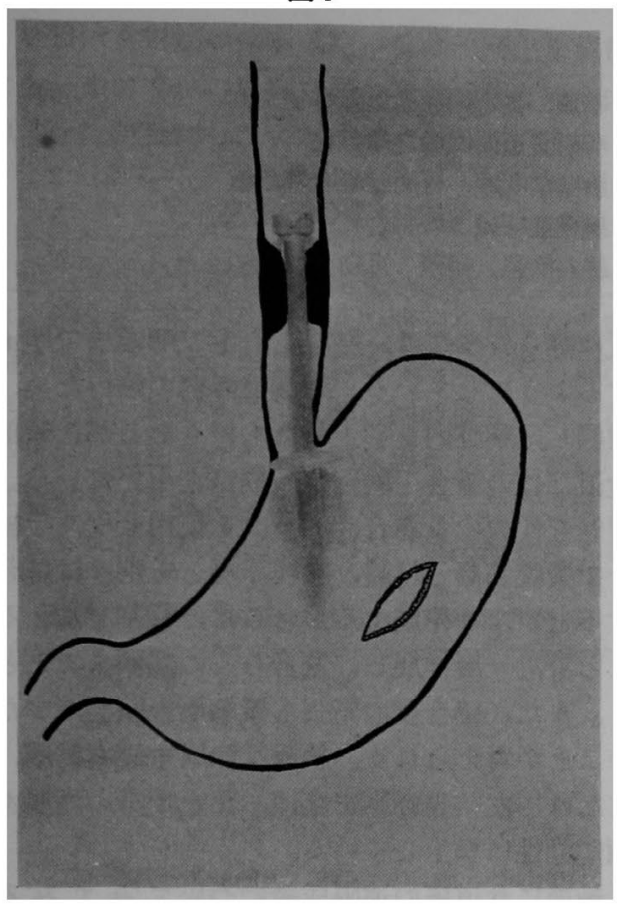

挿管用チェーブ (図 5 ) の先のパイロットブ ジーを胃切開口よりひき出し, ひつぱつてパイ ロットチェーブに続く本体を癌部に䈈在させて いる。この手術は侵襲が少なく，手技も容易 で，而も挿管 $2 \sim 3$ 日後から経口抒取ができる などの長所をもつている。

次に切除例についてみる。456例を再建術式 別にみてみると, 胸壁前食道胃（結腸）吻合が 347例 $(76 \%)$ と圧倒的に多く, 胸腔内食道胃 吻合74例 $(16 \%)$, 胸腔内食道空腸吻合 32 例 ( 7 $\%)$ ，胃管を後縦隔を通して挙上，頸部食道と 吻合したもの 3 例 (1\%) である。猶, 胸壁前 食道再建のうち, 再建臟器として結腸を用いた ものは $0.5 \%$ \%゙あ。

その各々の手術死亡率をみると, 胸壁前吻合 では $4.3 \%$ とかなり良好である。胸腔内食道空 腸吻合は，症例も少ないが，噴門部への浸潤の 及んだもの, 下部食道癌で胃切除の既往のある ものなどを対象としているが, 種々の合併症も おき, 高い死亡率を示している（表 7)。

胸壁前再建術は, 手術の安全性と癌の根治性 をたかめ,さらに, poor risk の際の分割手術が
表 7 胸部食道癌手術成績

(1965 1972) (456例)

\begin{tabular}{|c|c|c|c|}
\hline 式 & 症例数 $\mid$ & $\begin{array}{l}\text { 手術死 } \\
\text { 亡 例 }\end{array}$ & $\begin{array}{l}\text { 手術死 } \\
\text { 亡 率 }\end{array}$ \\
\hline 胸壁前食道胃吻合 & 347 & 15 & $4.3 \%$ \\
\hline 胸腔内食道胃吻合 & 74 & 5 & $6.7 \%$ \\
\hline 胸腔内食道空腸吻合 & 32 & 5 & $15.6 \%$ \\
\hline 経胸腔頸部食道胃吻合 & 3 & 0 & $0 \%$ \\
\hline
\end{tabular}

可能であるとか, また，容易に皮下の胃瘻より へ経管栄養がとれるなどの利点をもつている。 一方, 吻合部の㫥開の多いことは, この手術法 の唯一の欠点であつた。この哆開は皮下膿瘍, 瘦となって, 患者にとつては致命的ではない が, 非常に日常生活に悩まされるものである。 最近われわれは，この吻合部の哆開を防止する 術式について，1.2の工夫をおこなつている。 一つは, 挙上胃管の緊張をとり, 血流の改善 をはかるため, 吻合部を含め, 挙上胃管の先端 部付近を広範囲に漿膜筋層を剝離し, 胃管と異 る血流支配をうける大網片を作成, 胃管と一し よに挙上, 吻合部を含めて, 胃管を広く被覆す るもので, 副血行路の早期再開を期待する方法 である（図 6 ）。一方，大網に癌の転移の恐れ のあるとき, 大網が脂肪が多く厚く挙上胃管を かえつて圧迫してしま5ようなときなど大網を 使用できないことがあつて, 現在では, 挙上胃 管の緊張をとり, 伸展をはかるために, 胃管の 前庭部から吻合部付近、何本かの墏膜筋層に及 ぶ横割を加えている。小彎側切断端より幽門側 では全周性に, また切断部では, 小彎側の縫埋 部を僅かのこして, 前後壁, 大彎にかけて入

图 6 胃管先端部の漿膜筋層を広く剝離し, 食道 と胃との吻合部を大網片で被覆する
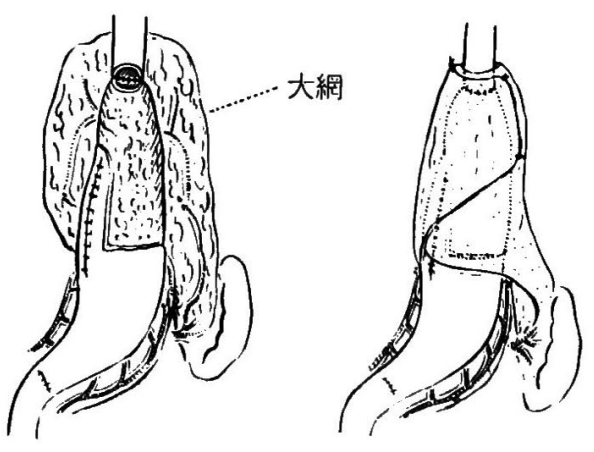
気食会報一 25 巻

図 7 挙上した胃管に粘膜下層までの全周性横割 を入れ，食道には外蒁筋のみの横割を入れ る。

食道と胃とは層別に 2 層に吻合する

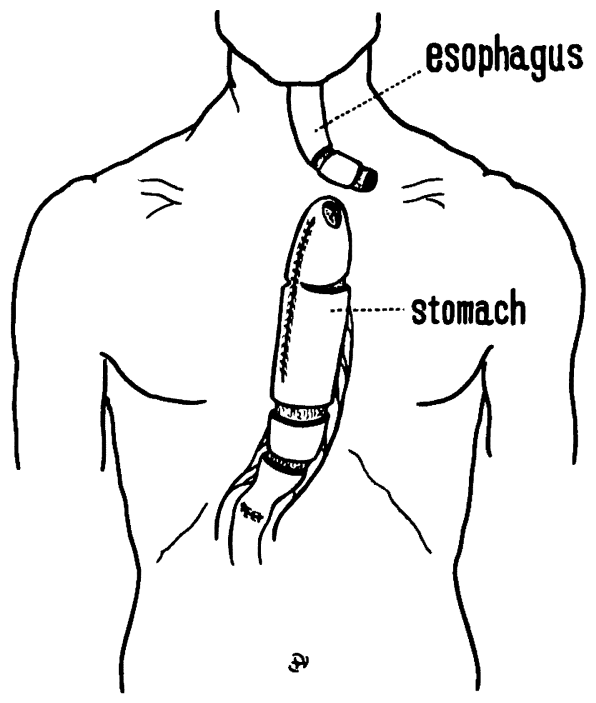

れ，1本の横割で胃管はらくに $1 \mathrm{~cm}$ は伸び， さらに緊張の低下がみられる。この横割は筋層 の厚い前庭部に近い程効率がよい(図 7 )。猶, 漿膜，筋層の横割は，臨床上胃の先端部の血流 に全く影響はなく，実際に Pletismograph によ る測定でも確かめている。

食道と胃管との吻合では，端々吻合，端側吻 合とも丁寧に層別に縫合している。つまり，外 層は食道の外膜, 筋層と, 胃の漿膜, 筋層とを 絹糸の結節縫合で，内層は粘膜，粘膜下層同士 を3-0の cat gutで，と分けて縫合してい る。

食道, 胃ともに, 粘膜下層で, loose になるの で，これらの層の確認は全く容易である。

このような術式のいくつかの工夫で，吻合部 の哆開率は改善され，以前 $40 \%$ も哆開率を， 10\%台にまで下げることができた。猶，大網使 用群と末使用群とでは前者が若干成績がよい。

次に, 下咽頭頸部食道癌についてみてみる と,この切除例は少ない。同期間に18例にすぎ ず，その再建術式としてて， S 状結腸を中心と した結腸や，小腸の遊離移植が約半数をしぬて いる（表 8)。しかし，数はまだ少ないが，最
表 8 頸部食道癌再建方法

(1965 1972)

\begin{tabular}{l|l} 
咽頭, 食道間結腸遊離移植 & 9 例 \\
咽頭食道間回腸遊離移植 & 2 \\
胸壁前咽頭, 胃間結腸有茎移植 & 2 \\
胸壁前咽頭, 胃吻合 & 3 \\
経右胸膑, 咽頭, 胃吻合 & 2 \\
\hline
\end{tabular}

近は専ら胃または, 結腸を有茥で咽頭まで挙上 するようにしている。頸胸境界部の癌のため, 開胸し，胸腔内を挙上したものもあるが，頸部 食道だけの場合, 胸壁前の経路を用いている。 胃管を作成する場合, ペッツを使用せす，手縫 いで漿膜筋層と粘膜, 粘膜下層とを別々に縫合 するとかなり伸展するがさらに，横割を加える ことで，一層伸展し，割合らくに咽頭までとど く。また，縫合後の緊張も漿筋層の断裂で少な いことが考えられる。結腸は回腸末端右結腸, なたは，左結腸動脈を茥にした左半分の結腸を 順蠕動性に挙上している。

最後に食道癌の遠隔成績についてみてみる と，1965年から1968年までの胸部食道癌手術例 114 例中 5 年以上生存例は 22 例で, 5 年生存率 は19.2\%である（図 8 ）。この值は，丁度10年 前, 中山の千葉大学第 2 外科での成績 $15 \%$ に比 べる若干上昇しているよらであるが術中術後 の管理, 合併療法の進歩など, 食道外科の進歩 と癌に対する合併療法の進歩などがめざましい 割りに成績の向上のみられないところである。

また，頸部食道癌の長期生存例はもつと少な く，いつれも，術前にコバルト照射の終了した

图 8

\section{胸部食道虑術後逵隔成綪}

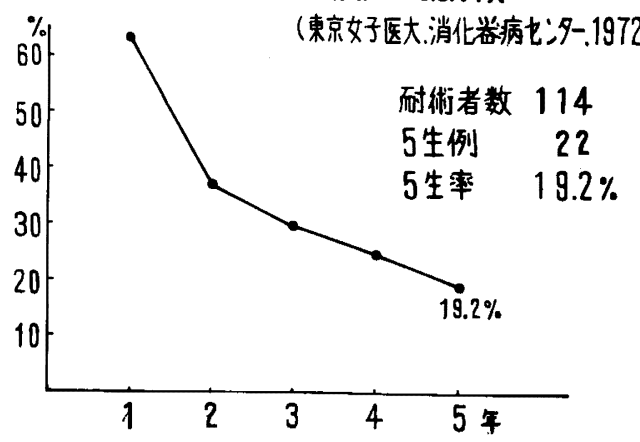


例のみである。

今後, 食道癌の遠隔成績の飛躍的向上を望む なら,やはり癌の早期発見, 早期治療という大 原則を，再確認したいところである。

\section{$\mathrm{V}$ 食道癌の定期検診}

消化器癌の早期発見をめざし, 当センターで は, 消化器を中心に年 2 回の検查をおこなう定 期検診制度を1967年よりおこなつている。1972 年末まで, 1407 人に，延8212回の検査をおこな つたが, 発見された消化器疾患として, 胃癌は 早期癌 4 例を含み，10例であるが，食道癌は 1 例もみられなかつた（表 9 )。集団検診による

表 9 定期検診でみつけられた消化器疾患

\begin{tabular}{l|r}
\hline 食道睻室 & 18 \\
食道粘膜下腫瘍 & 1 \\
食道ポリープ & 1 \\
食道裂孔ヘルニ? & 16 \\
胃 癌 & 10 \\
胃・十二指腸溃瘍 & 112 \\
胃隆起性病変 & 27 \\
直 腸 癌 & 1 \\
胆 石 症 & 41 \\
\hline
\end{tabular}

食道癌の発見頻度は文献上も胃癌に比べてかな り低く, 例えば有森らは, 慶応がんセンターで の 3 年間の 5752 例, 延 14462 回の検查で, 1 例 (0.02\%) とし, 佐藤らは，4年間での延 2836 回の集検で，食道癌は 1 例もなかつたとしてい る。しかし，飯塚は，中国見学記のなかで，食 道癌多発地区で, 30 才以上の人に強制的に細胞 診による集検をおこなつたところ，発見された 食道癌のなかで70\%は早期癌であると述べてい る。因に, 同地区の病院ではその比率は $6.8 \%$ とへり，また集検でも，有愁訴者のみを対象と したものでは16\%にしかならないという数字を あげ，無愁訴例への集検の必要性をのべてい る。わが国でも，早期癌を発見するにはやはり このような無愁訴例を対象とした検査をやらな くてはならないといえると思う。その検索方法 として,わが国では内視鏡の発達のめざましい ところから，内視鏡検查をもつと活用していく ことが必要と思う。例えば経 $7 \mathrm{~mm}$ の細径食道
ファイバースコープがある。少し写真が悪いと いう久点はあるが，観察をはじめ，他の機能面 では通常のものと全く同じである。このような 細いものでは患者の苦痛も少なく, 集検には適 していると思う。外来患者ではあるが，初診日 に無選択に，また食事摂取の有無に関係なく， このスコープを使用してみたが，咽頭麻酔のみ による使用経験でも，途中で中止したものは 127 例中 7 例 $(5 \%)$ で，あとは，食道に関し てはいうれれも所見をつかみえた。

当消化器病センターでの表在癌は18例で, こ のうち手術によりリンパ節転移のなかつた早期 癌は14例である。これら表在癌の主訴をみてみ ると, 食道の不定愁訴が一番多い。また胸痛を 訴えてくることもあり，1例は全くの無症状 で, 偶々胃の定期検診の際, 偶然にみつけられ たものである。そこで現状では，食道に関する 愁訴のある場合には勿論であるが，長い間つゔ く胸痛などの場合でも一応食道もチュックする 必要がある。さらに現状では, 胃のX線検査を する際, また, 胃の集検をおこなう際にも, 食 道の立位, 第 1 , 第 2 斜位での二重造影像を必 ずとるようにするのが妥当と考えている。食道 の小病変は二重造影像が一番わかり易く, これ

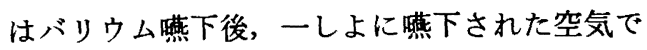
つくられる自然の二重造影像でよい。あとから みて, これで少しでも疑わしいときは, 内視鏡 検查なり，X線の精検なりをおこなうようにし ている。

\section{VI ま め}

以上, 当消化器病センターの食道診療の現状 についてみてみたが，食道疾患のなかでは，や はり食道癌の診断と治療が一番の問題である。 まだまだ解決されないところも多いのである が，その早期発見，早期治療という目標だけは 既にきまつているので，今後ともこの目標に向 けながらすすめていくのが本筋のように思え る。このよらな材料が少しでも「気管食道科の 診療の将来」というテーマの参考になればと思 い報告した次第である。

（本論文の要旨は第25回本学会総会において発表 した。 
気 食会報一 25 巻

\section{参考文献}

1. 小林誠一郎他：食道の二重造影法, 胃と腸, 5: 1279, 1970

2) 有森正樹他：食道癌のX線集団検診, 食道癌早 期発見のための食道胃同時集検について，外科診 療, $12: 1434,1970$.

3）佐藤博他：食道胃同時集団検診について，胃癌 と集団検診， $17: 5152 ， 1969$.

4 ）羽生富士夫他：食道癌に対する胸部食道全剔, 胸壁前食道胃吻合術, 臨床外科, $26: 731,1971$.

5 ）遠藤光夫他：早期食道癌の臨床的検討, 気食会 報, $23: 213,1972$.
6 ）中山恒明, 遠藤光夫 : 食道癌の診断と治療の進 歩, 臨牀之研究, $49: 2405,1972$.

7 ）三輪剛他：スクリーニング用食道ファイバース コープ, Gastroenterologlcal Endoscopy, $13: 422$, 1971.

8 ）遠藤光夫他：食道ファイバースコープによる食 道及び胃内異物の摘出, Gastroenterological Endoscopy, $16: 112,1974$.

9 ）遠藤光夫他：食道再建術々後吻合部狭窄に対す る抎張法の 1. 2 の工夫, 特に先端屈曲可能ブジ 一と食道ファイバースコープ直視下焼灼につい て, 気食会報, $24: 177,1973$. 